\title{
Genetic Parameters Study for Yield and Yield Contributing Characters in Rice (Oryza sativa L.) Genotypes with High Grain Zinc Content
}

\author{
Partha Pratim Behera $^{1 *}$, S. K. Singh ${ }^{1}$, D. K. Singh ${ }^{1}$ and Khonang Longkho ${ }^{2}$ \\ ${ }^{1}$ Department of Genetics and Plant Breeding, Banaras Hindu University, \\ Varanasi- 221 005, India \\ ${ }^{2}$ Department of Genetics and Plant Breeding, Visva Bharat, West Bengal, India \\ *Corresponding author
}

Keywords

Genetic variability, GCV, PCV,

Heritability,

Genetic advance,

Analysis of

variance

Article Info

Accepted:

05 February 2020

Available Online:

10 March 2020
The present investigation for genetic variability was made based on the data recorded for sixteen yield and yield contributing quantitative and qualitative characters in twenty one rice genotypes using statistical tool.There are significant differences among the genotypes for all the characters under study showed by analysis of variance. Among the characters, higher estimates of phenotypic coefficient of variance (PCV) and genotypic coefficient of variance (GCV) were observed for the traits number of spikelet per panicle, no of filled grains per panicle, grain weight per panicle(g) and grain yield/ha $(\mathrm{kg})$. This indicates the existence of wide genetic base among the genotypes taken for study and higher possibility of genetic improvement through selection for these traits. Heritability was higher for all the characters except tillers per plant, spikelet fertility per cent and panicle length $(\mathrm{cm})$. Thus, selection based on phenotypic values would be effective for these traits. High heritability coupled with high genetic advance as per cent of mean was recorded for the characters; days to first flowering, days to 50 per cent flowering, number of filled grains per panicle, number of spikelet per panicle, grain yield per plot $(\mathrm{kg})$, grain weight per panicle $(\mathrm{g})$, grain yield per plant $(\mathrm{g}), 1000$ grains weight $(\mathrm{g})$, grain zinc content $(\mathrm{ppm})$ and grain yield/ha $(\mathrm{kg})$. These characters indicate the predominance of additive gene effects in their expression and would respond to selection effectively as they are least influenced by environment which can be improved through simple selection. 


\section{Introduction}

Rice (Oryza sativa L.) is a short day monocotyledonous self-pollinated angiosperm within the genus Oryza of family Poaceae. It is the principal nourishment for $33 \%$ of the total population and involves very closely one-fifth of the aggregate land territory occupied under cereals (Ren et al., 2006). ). Rice is produced in 114 countries across the globe estimating production of $753 \mathrm{mt}$ (499mt milled rice, 2016) and forecasting $758 \mathrm{mt}$ (503.6mt milled rice, 2017) with world rice acreage of 161.1 mha (FAO, 2017). Among the rice growing countries in the world, India occupied the largest area under rice crop (about 45 million ha.) having the second position in production next to China, (IRRI 2016, standard evaluation system for rice.). As world's population is growing in exponential rate and maintain the food security as per the need is a challenging task for us as it is faced by so many constraints due to climate change. Variability is a vital factor which determines the amount of progress expected from selection. As phenotypic variation does not directly show its effectiveness for selection to obtain genetic improvement unless the genetic fraction of variation is known. Hence, an insight into the magnitude of genetic variability available is of paramount importance to a plant breeder for starting a prudent breeding programme. It becomes necessary to partition the phenotypic variability into heritable and non-heritable components with the help of genetic parameters such as genotypic and phenotypic co-efficient, heritability and genetic advance to facilitate selection. The variances were expressed as coefficient of variation so as to facilitate their comparison amongst different characters. The phenotypic co-efficient of variation was in general, higher than the genotypic co-efficient of variation. But the differences between PCV and GCV for many traits were less, suggesting the less impact of environment for the traits. An estimate of heritability and genetic advance for different characters ultimately provides an appropriate guideline for selection and also the expected genetic gain. A quantitative measure which delivers information about the correspondence between genotypic variance and phenotypic variance is heritability. Achievement of a breeder in changing the characteristics of a population is subjected to heritability that is, the degree of correspondence between genotypic and phenotypic variance. Heritable improvement in yield is the ultimate object of plant breeder which calls for selection on the basis of yield components which are heritable. It becomes very important for breeders to go for selection of elite genotype from diverse population which helped by estimates of heritability. However, high heritability estimates coupled with high genetic advance render the selection most effective (Johnson et al., 1955).

\section{Materials and Methods}

This experiment was conducted to study the genetic variability for yield and yield contributing traits among twenty-one diverse rice genotypes with high grain Zinc content collected from IRRI South Asia Hub, Hyderabad (Table.1) over five different locations i.e. (I) Agricultural Research Farm, Institute of Agricultural Sciences, Banaras Hindu University, Varanasi, UP,(II) Agricultural Research Farm, Institute of Agricultural Sciences, Banaras Hindu University, Varanasi, UP (III) Bhikaripur, Varanasi, UP (IV) Karsada, Varanasi, UP (V) Rampur, Mirzapur, UP during Kharif 2017. Net Plot size was $2.4 \mathrm{~m} \times 2.4 \mathrm{~m}$, twelve rows were grown having inter and intra row spacing was $20 \mathrm{~cm}$ and $15 \mathrm{~cm}$ respectively for each location under study. They were grown in a randomized block design with three replications and observations were recorded on randomly selected five plants for the 
sixteen quantitative and qualitative traits i.e days to first flowering, days to $50 \%$ flowering, days to maturity, number of effective tillers per plant, plant height $(\mathrm{cm})$, panicle length $(\mathrm{cm})$, number of spikelet per panicle, number of filled grains per panicle, spikelet fertility per cent, grain weight per panicle (g), grain yield per plant (g), 1000grain weight $(\mathrm{g})$, Grain yield per plot $(\mathrm{kg})$, Grain yield per ha $(\mathrm{kg}), \mathrm{L} / \mathrm{B}$ ratio, and grain zinc content $(\mathrm{mg} / \mathrm{kg})$ were considered. Zinc content of rice grains was estimated in the aliquot of seed extract by using Atomic Absorption Spectrophotometer (AAS) at $213.86 \mathrm{~nm}$ for Zinc. The genotypic and phenotypic variances, genotypic (GCV) and phenotypic (PCV) coefficient of variation were estimated according to formula given by Burton (1952). Heritability in broad sense $\left[\mathrm{h}^{2}\right.$ (b)] was estimated according to formula given by Lush (1940) and genetic advance and Genetic advance as per cent of mean were estimated as formula suggested by Johnson et al., (1955) by using suitable statistical tool.

\section{Results and Discussion}

Based on the Pooled analysis of variance (ANOVA) (Table 2) revealed that there is significant variation exists among the twenty one genotypes for all the sixteen characters over the five locations which will favourable for efficient selection. Among the characters, higher estimates of PCV and GCV were observed respectively for the traits, number of spikelet per panicle (PCV $=32.85 \%$, $\mathrm{GCV}=29.99 \%$ ), number of filled grains per panicle $(32.19 \%, 29.07 \%)$ and grain weight per panicle(g) $(30.66 \%, 27.01 \%)$ (Table 3). This indicates the existence of wide genetic base among the genotypes taken for study and possibility of genetic improvement through selection for these traits. This was in conformity with the findings of Reddy De et al., (1998) who reported higher PCV and $\mathrm{GCV}$ in rice for no of spikelet per panicle, grain weight per panicle and number of filled grains per panicle. Mahto et al., (2003), Satyanarayana et al., (2005) and Singh et al., (2007) also reported similar findings in upland rice for the grains per panicle. Moderate estimates of PCV and GCV were observed for the traits, days to first flowering $(10.67 \%, 10.58 \%)$, number of effective tillers per plant $(17.45 \%, 12.40 \%), 1000$ grain weight $(g)(16.71 \%, 15.62 \%)$ and grain zinc content (ppm) $(18.08 \%, 15.5 \%)$ respectively. This suggests that the genetic improvement through selection for these traits may not be always effective. Similar results were also obtained by Dhurai et al., (2014) and Dhanwani et al., (2013) in rice reported for panicle length and other yield attributes. Low estimates of PCV and GCV were observed respectively for the characters days to $50 \%$ flowering $(10.05 \%, 9.99 \%)$, days to maturity $(8.41 \%, 8.36 \%)$ and spikelet fertility percent (7.95\%, 5.26\%), pant height $(8.94 \%, 7.26 \%)$, panicle length $(8.61 \%, 6.55 \%)$ and LB ratio $(9.37 \%, 8.73 \%)$ suggesting that the direct selection for these traits may not be rewarding. The similar results were also reported by Kaw et al., (1995), Muthuramu et al., (2016) for days to maturity in cold stress environment. The estimate of heritability ranged from $46.4 \%$ (spikelet fertility percent) to $98.8 \%$ (Days to $50 \%$ Flowering). Percentage of heritability was higher for all the characters except spikelet fertility percent (46.4\%), panicle length (58.16\%) and number of effective tillers per Plant $(50.41 \%)$ (Table 3), similar study conducted by Satyanarayana et al., (2005) in rice for panicle lengths and number of effective tillers per plant found to be not effective for selection due to low heritability. Thus, selection based on phenotypic values would be effective for these traits. These findings are in agreement with those of Kundu et al., (2008) for number of filled grains per panicle and 1000-grain weight in tall indicaaman rice and Kole and Hasib (2008) for plant height, days to $50 \%$ 
flowering, panicle length, kernel length and kernel L/B ratio in scented rice. In the present study most of the characters recorded high heritability estimates and selection would be effective if based on phenotypic values. High heritability coupled with high genetic advance as per cent of mean was recorded respectively for the characters, days to first flowering [h 2 (broad sense $)=98.34 \%$ and $\mathrm{GA}(\%$ per mean) $=21.62 \%]$, days to $50 \%$ percent flowering $(98.8 \%, \quad 20.46 \%)$, spikeletper panicle $(83.38 \%, 56.44 \%)$, filled grains per panicle $(81.48 \%, 54.13 \%)$, grain weight per panicle $(\mathrm{g})(77.66 \%, 49.05 \%)$, grain yield per plant $(\mathrm{g})(64.57 \%, 30.35 \%)$, grain yield per plot $(\mathrm{kg})(64.52 \%, 30.33 \%)$, grain zinc content $(\mathrm{mg} / \mathrm{kg}) \quad(75.67 \%, \quad 27.73 \%) \quad$ and yield/ha rainfed $(\mathrm{kg})(64.59 \%, \quad 30.35 \%)$
(Table.3). These results are similar with the results obtained by Gyanendrapal et al., (2011) for grain yield per plant, spikelet per panicle, effective tillers per plant and days to 50\% flowering, Krishna et al., (2010) for number of total spikelets per panicle and number of filled grains per panicle, Anjaneyulu et al., (2010), Bhinda et al., (2017) for number of filled grains per panicle, Kundu et al., (2008) for grain yield per plant and 1000-grain weight in tall indicaaman rice and Singh et al., (2007) for days to 50\% flowering and grains per panicle. These characters indicate the predominance of additive gene effects in their expression and would respond to selection effectively as they are least influenced by environment.

Table.1 List of 21 genotypes collected from IRRI South Asia Hub, Hyderabad

\begin{tabular}{|l|l|l|l|l|c|}
\hline $\begin{array}{l}\text { SL.N } \\
o\end{array}$ & Name of Genotype & $\begin{array}{l}\text { Grain Zinc } \\
\text { Content (ppm) }\end{array}$ & SL.No & Name of Genotype & $\begin{array}{l}\text { Grain Zinc } \\
\text { Content } \\
\text { (ppm })\end{array}$ \\
\hline 1 & $\begin{array}{l}\text { IR 95044:8-B-5-22- } \\
\text { 19-GBS }\end{array}$ & $\mathbf{2 0 . 6}$ & 12 & BRRIdhan 64 & $\mathbf{2 4 . 9 7}$ \\
\hline 2 & $\begin{array}{l}\text { IR 84847-RIL 195- } \\
\text { 1-1-1-1 }\end{array}$ & $\mathbf{2 1 . 8}$ & 13 & BRRIdhan 72 & $\mathbf{2 0 . 7}$ \\
\hline 3 & IR 99704-24-2-1 & $\mathbf{1 4 . 6 7}$ & 14 & DRR Dhan 45 & $\mathbf{1 8 . 1 3}$ \\
\hline 4 & IR 99647-109-1-1 & $\mathbf{2 3 . 7}$ & 15 & DRR Dhan 48 & $\mathbf{1 9 . 2}$ \\
\hline 5 & $\begin{array}{l}\text { IR 97443-11-2-1-1- } \\
\text { 1-1 -B }\end{array}$ & $\mathbf{1 4 . 4 5}$ & 16 & DRR Dhan 49 & $\mathbf{1 7 . 6 3}$ \\
\hline 6 & $\begin{array}{l}\text { IR 97443-11-2-1-1- } \\
\text { 1-3 -B }\end{array}$ & $\mathbf{2 3 . 4 7}$ & 17 & IR 64 & $\mathbf{2 3 . 5 7}$ \\
\hline 7 & $\begin{array}{l}\text { IR 82475-110-2-2- } \\
\text { 1-2 }\end{array}$ & $\mathbf{2 4 . 7 3}$ & 18 & MTU101 & 21.70 \\
\hline 8 & $\begin{array}{l}\text { IR 96248-16-3-3-2- } \\
\text { B }\end{array}$ & $\mathbf{2 7 . 1 8}$ & 19 & Sambamahsuri & $\mathbf{2 4 . 4 7}$ \\
\hline 9 & $\begin{array}{l}\text { R-RHZ- } \\
7\end{array}$ & $\mathbf{2 6 . 6 1}$ & 20 & Swarna & $\mathbf{1 8 . 8 9}$ \\
\hline 10 & CGZR-1 & $\mathbf{2 4 . 4 3}$ & 21 & $\begin{array}{l}\text { Local } \\
\text { check }\end{array}$ & $\mathbf{1 6 . 9}$ \\
\hline 11 & BRRIdhan 62 & $\mathbf{2 3 . 3 3}$ & & & \\
\hline
\end{tabular}


Table.2 Pooled ANOVA of twenty one rice genotypes for sixteen characters over the five different locations

\begin{tabular}{|c|c|c|c|c|c|c|c|c|c|c|c|c|c|c|c|c|}
\hline $\begin{array}{c}\text { Entry } \\
\text { No }\end{array}$ & $\begin{array}{c}\text { Days to } \\
\text { 1st } \\
\text { flowering }\end{array}$ & $\begin{array}{c}\text { Days to } \\
50 \% \\
\text { Flowering }\end{array}$ & $\begin{array}{l}\text { Days to } \\
\text { Maturity }\end{array}$ & $\begin{array}{l}\text { Tillers } \\
\text { Per } \\
\text { Plant }\end{array}$ & $\begin{array}{l}\text { Plant } \\
\text { Height } \\
\text { (cm) }\end{array}$ & $\begin{array}{l}\text { Panicle } \\
\text { Length } \\
\text { (cm) }\end{array}$ & $\begin{array}{c}\text { Spikelets } \\
\text { Per } \\
\text { Panicle }\end{array}$ & $\begin{array}{l}\text { Filled } \\
\text { grains } \\
\text { Per } \\
\text { Panicle }\end{array}$ & $\begin{array}{l}\text { Spikelet s } \\
\text { Fertility\% }\end{array}$ & $\begin{array}{l}\text { Grain } \\
\text { Weight } \\
\text { Per } \\
\text { Panicle } \\
\text { (g) }\end{array}$ & $\begin{array}{c}\text { Grain } \\
\text { Yield } \\
\text { Per } \\
\text { Plant } \\
\text { (g) }\end{array}$ & $\begin{array}{c}\text { 1000- } \\
\text { grain } \\
\text { Weight } \\
\text { (g) }\end{array}$ & $\begin{array}{c}\text { Grain } \\
\text { Yield } \\
\text { Per } \\
\text { Plot } \\
(\text { kg) }\end{array}$ & $\begin{array}{c}\text { Grain } \\
\text { Yield/ha } \\
\text { (kg) }\end{array}$ & $\begin{array}{c}\text { L/B } \\
\text { Ratio }\end{array}$ & $\begin{array}{c}\text { Grain } \\
\text { Zinc } \\
\text { content } \\
(\mathbf{p p m})\end{array}$ \\
\hline Mean & 93.746 & 98.181 & 126.800 & 7.873 & 106.7 & 26.013 & 109.300 & 83.121 & 76.374 & 1.507 & 11.618 & 18.258 & 0.941 & 3920.880 & 4.000 & 22.158 \\
\hline C.V. & 1.361 & 1.094 & 0.932 & 12.206 & 5.000 & 5.551 & 13.281 & 13.684 & 5.818 & 14.420 & 13.086 & 5.844 & 13.106 & 13.086 & 3.288 & 8.476 \\
\hline F ratio & 186.887 & 253.998 & 249.311 & 4.185 & 9.848 & 5.434 & 17.245 & 15.323 & 4.230 & 12.128 & 7.114 & 24.481 & 7.092 & 7.116 & 27.359 & 24.727 \\
\hline F Prob. & $0.00 \mathrm{E}+00$ & 0 & 0 & 0 & 0 & 0 & 0 & 0 & 0 & 0 & 0 & 0 & 0 & 0 & 0 & 0 \\
\hline S.E. & 1.036 & 0.872 & 0.960 & 0.784 & 4.321 & 1.175 & 11.923 & 9.307 & 3.647 & 0.173 & 1.168 & 0.864 & 0.095 & 394.053 & 0.107 & 1.470 \\
\hline $\begin{array}{l}\text { C.D. } \\
5 \%\end{array}$ & 2.094 & 1.763 & 1.939 & 1.584 & 8.732 & 2.374 & 24.098 & 18.810 & 7.370 & 0.350 & 2.360 & 1.745 & 0.191 & 796.415 & 0.217 & 2.971 \\
\hline $\begin{array}{l}\text { C.D. } \\
1 \%\end{array}$ & 2.802 & 2.359 & 2.595 & 2.120 & 11.685 & 3.177 & 32.246 & 25.171 & 9.863 & 0.468 & 3.158 & 2.335 & 0.256 & 1065.700 & 0.290 & 3.976 \\
\hline $\begin{array}{l}\text { Range } \\
\text { Lowest }\end{array}$ & 80.267 & 85.000 & 111.800 & 6.06 & 98.43 & 23.41 & 70.4 & 54.13 & 71.6 & 1.023 & 8.97 & 13.82 & 0.726 & 3027.49 & 3.2 & 16.64 \\
\hline $\begin{array}{l}\text { Range } \\
\text { Highest }\end{array}$ & 114.800 & 119.000 & 148.333 & 9.733 & 128.08 & 30.30 & 185 & 136.6 & 81.67 & 2.182 & 14.57 & 21.76 & 1.18 & 4919.43 & 4.45 & 26.64 \\
\hline
\end{tabular}


Table.3 Heritability (broad-sense), GCV, PCV and Genetic advance as per cent of mean of twenty one rice genotypes for sixteen characters over the five different locations

\begin{tabular}{|c|c|c|c|c|c|c|c|c|c|c|c|c|c|c|c|c|}
\hline & $\begin{array}{c}\text { Days to } \\
\text { first } \\
\text { flowering }\end{array}$ & $\begin{array}{c}\text { Days to } 50 \\
\% \\
\text { Flowering }\end{array}$ & $\begin{array}{c}\text { Days to } \\
\text { Maturity }\end{array}$ & $\begin{array}{c}\text { Effective } \\
\text { Tillers } \\
\text { Per Plant }\end{array}$ & $\begin{array}{c}\text { Plant } \\
\text { Height } \\
\text { (cm) }\end{array}$ & $\begin{array}{c}\text { Panicle } \\
\text { Length } \\
\text { (cm) }\end{array}$ & $\begin{array}{l}\text { Spikelets } \\
\text { Per Paniclf }\end{array}$ & $\begin{array}{c}\text { Filled } \\
\text { grains Pei } \\
\text { Panicle }\end{array}$ & $\begin{array}{c}\text { Spikelets } \\
\text { Fertility \% }\end{array}$ & $\begin{array}{c}\text { Grain } \\
\text { Weight Per } \\
\text { Panicle(g) }\end{array}$ & $\begin{array}{l}\text { Grain } \\
\text { Yield Per } \\
\text { Plant (g) }\end{array}$ & $\begin{array}{l}\text { 1000-grain } \\
\text { Weight (g) }\end{array}$ & $\begin{array}{l}\text { Grain } \\
\text { Yield Per } \\
\text { Plot (kg) }\end{array}$ & $\begin{array}{c}\text { Yield/ ha } \\
\text { (kg) }\end{array}$ & $\begin{array}{c}\text { L/B } \\
\text { Ratio }\end{array}$ & $\begin{array}{c}\text { Grain Zinc } \\
\text { content } \\
(\text { ppm })\end{array}$ \\
\hline Var Environmental & 1.63746 & 1.155397 & 1.405397 & 0.9254 & 29.7057 & 2.08942 & 233.6224 & 139.858 & 21.66341 & 0.0484183 & 2.157278 & 1.128295 & 0.01418 & 245718 & 0.018 & 3.987831 \\
\hline ECV & 1.360573 & 1.09444 & 0.932205 & 12.2055 & 5.000082 & 5.55101 & 13.28061 & 13.6836 & 5.818053 & 14.420084 & 13.08637 & 5.843566 & 13.1052 & 13.086 & 3.288 & 8.476248 \\
\hline VarGenotypical & 98.11333 & 95.99508 & 112.4733 & 1.00349 & 61.52866 & 2.96129 & 1127.157 & 590.055 & 16.85615 & 0.1685124 & 3.80825 & 8.531916 & 0.02499 & 433942 & 0.123 & 12.0755 \\
\hline GCV & 10.58295 & 9.994176 & 8.364306 & 12.4047 & 7.265034 & 6.55156 & 29.99571 & 29.0729 & 5.266001 & 27.01118 & 18.13647 & 15.62485 & 18.1344 & 18.14 & 8.73 & 15.50079 \\
\hline VarPhenotypical & 99.75079 & 97.15048 & 113.8787 & 1.92889 & 91.23436 & 5.05071 & 1360.78 & 729.913 & 38.51956 & 0.2169307 & 5.965528 & 9.660211 & 0.03917 & 679661 & 0.141 & 16.06333 \\
\hline PCV & 10.67104 & 10.05414 & 8.416493 & 17.451 & 8.945215 & 8.61475 & 32.85638 & 32.1909 & 7.957148 & 30.663744 & 22.5036 & 16.71846 & 22.5114 & 22.506 & 9.371 & 18.08228 \\
\hline $\mathbf{h}^{2}($ Broad Sense $)$ & 0.983438 & 0.988084 & 0.987613 & 0.50414 & 0.669151 & 0.5816 & 0.833896 & 0.81481 & 0.464045 & 0.7766145 & 0.645785 & 0.870445 & 0.6452 & 0.6459 & 0.867 & 0.756761 \\
\hline $\begin{array}{l}\text { Gen.Adv as \% of } \\
\text { Mean 5\% }\end{array}$ & 21.621 & 20.46522 & 17.12366 & 18.2631 & 12.33268 & 10.3125 & 56.4474 & 54.1333 & 7.41412 & 49.05292 & 30.35108 & 30.1008 & 30.3314 & 30.358 & 16.78 & 27.73214 \\
\hline General Mean & 93.74603 & 98.18095 & 126.8095 & 7.87302 & 106.7231 & 26.0127 & 109.2857 & 83.1206 & 76.37397 & 1.5067016 & 11.61752 & 18.25813 & 0.94109 & 3920.9 & 4 & 22.15819 \\
\hline
\end{tabular}


In conclusion, there are significant differences among the genotypes for all the characters under study showed by analysis of variance. This indicated that there is ample scope for selection of promising genotypes from present set of genotypes for yield improvement. Among the characters, higher estimates of PCV and GCV were observed for the traits number of spikelet per panicle, no of filled grains per panicle, grain weight per panicle $(g)$ and grain yield/ha $(\mathrm{kg})$. This indicates the existence of wide genetic base among the genotypes taken for study and higher possibility of genetic improvement through selection for these traits. Heritability was higher for all the characters except tillers per plant, spikelet fertility percent and panicle length $(\mathrm{cm})$. Thus, selection based on phenotypic values would be effective for these traits. High heritability coupled with high genetic advance as per cent of mean was recorded for the characters; days to first flowering, days to 50 percent flowering, number of filled grains per panicle, number of spikelet per panicle, grain yield per plot $(\mathrm{kg})$, grain weight per panicle(g), grain yield per plant (g), 1000 grains weight $(\mathrm{g})$, grain zinc content (ppm) and grain yield/ha $(\mathrm{kg})$. These characters indicate the predominance of additive gene effects in their expression and would respond to selection effectively as they are least influenced by environment which can be improved through simple selection. Pedigree method of breeding can be used for improving the characters influenced by additive gene action, whereas the characters influenced by additive and non-additive and only by non-additive gene actions can be improved through population improvement methods like recurrent selection or by employing biparental mating in the early generations followed by selection.

\section{References}

Anjaneyulu, M., Reddy, D. R., \& Reddy, K. H. P. (2010). Genetic variability, heritability and genetic advance in rice (Oryza sativa L.). Research on Crops, 11(2), 415-416.

Bhinda, M. S., and Karnwal, M. K. (2017). Estimates of genetic divergence in advance breeding lines of rice (Oryza sativa L.). Environment and Ecology, 35(4C), 3289-3292.

Burton, G. W. (1952, August). Qualitative inheritance in grasses. In Proceedings of the 6 th International Grassland Congress, Pennsylvania State College, $1,17-23$.

Dhanwani, R. K., Sarawgi, A. K., Solanki, A., \& Tiwari, J. K. (2013). Genetic variability analysis for various yield attributing and quality traits in rice $(O$. sativa L.). The Bioscan, 8(4), 14031407.

Dhurai, S. Y., Bhati, P. K., \&Saroj, S. K. (2014). Studies on genetic variability for yield and quality characters in rice (Oryza sativa L.) under integrated fertilizer management. The Bioscan, 9(2), 745-748.

Gyanendra, P., Verma, O. P., Verma, G. P., Narendra, P., Manoj, K., Chaudhary, R. K., \& Karan, S. (2011). Genetic variability, heritability and divergence studies in rice (Oryza sativa L.) under sodic soil. Environment and Ecology, 29(3B), 1597-1600.

Johnson, H. W., Robinson, H. F. and Comstock, R. E. (1955). Estimation of genetic and environmental variability in soybean. Agronomy Journal, 47(7), 314-318.

Kaw, R. N. (1995). Analysis of divergence in some cold-tolerant rices. The Indian Journal of Genetics and Plant Breeding, 55(1), 84-89.

Kole, P. C., and Hasib, K. M. (2008). Correlation and regression analysis in scented rice. Madras Agricultural Journal, 95(1/6), 178-182.

Krishna, T., Kavita, A., and Pushpalata, T. 
(2010). Genetic variability, heritability and genetic advance for quantitative traits in rice (Oryza sativa L.) accession. Agricultural \& Biological Research, 26(1), 13-19.

Kundu, A., Senapati, B. K., Bakshi, A., and Mandal, G. S. (2008). Genetic variability of panicle characters in tall indicaaman rice. ORYZA-An International Journal on Rice, 45(4), 320-323.

Lush, J. L. (1940). Intra-sire correlations or regressions of offspring on dam as a method of estimating heritability of characteristics. Proceedings of the American Society of Animal Nutrition, 1940(1), 293-301.

Mahto, R. N., Yadava, M. S., and Mohan, K. S. (2003). Genetic variation, character association and path analysis in rainfed upland rice. Indian Journal of Dryland Agricultural Research and Development, 18(2), 196-198.

Muthuramu, S., and Sakthivel, S. (2016). Genetic Variability Studies in Rainfed
Rice (Oryza sativa L.). Journal of Rice Research, 9(2).

Reddy, J. N., Pani, D., and Roy, J. K. (1998). Genotype $\mathrm{x}$ environment interaction for grain yield in lowland rice cultivars. Indian Journal of Genetics \& Plant Breeding (India).

Ren, X., Zhu, X., Warndorff, M., Bucheli, P., and Shu, Q. (2006). DNA extraction and fingerprinting of commercial rice cereal products. Food research international, 39(4), 433-439.

Satyanarayana, P. V., Srinivas, T., Reddy, P. R., Madhavilatha, L., and Suneetha, Y. (2005). Studies on variability, correlation and path coefficient analysis for restorer lines in rice (Oryza sativa L.). Research on Crops, 6(1), 80.

Singh, M., Kumar, K., and Singh, R. P. (2007). Study of coefficient of variation, heritability and genetic advance in hybrid rice. ORYZA-An International Journal on Rice, 44(2), 160-162.

\section{How to cite this article:}

Partha Pratim Behera, S. K. Singh, D. K. Singh and Khonang Longkho. 2020. Genetic Parameters Study for Yield and Yield Contributing Characters in Rice (Oryza sativa L.) Genotypes with High Grain Zinc Content. Int.J.Curr.Microbiol.App.Sci. 9(03): 357-364. doi: https://doi.org/10.20546/ijcmas.2020.903.042 